Acta vet. scand. $1981,22,480-492$.

From the Departments of Pathology and Clinical Chemistry, Faculty of Veterinary Medicine, Swedish University of Agricultural Sciences,

Uppsala, Sweden.

\title{
INFLUENCE OF STRESS ON SOME BLOOD CONSTITUENTS IN REINDEER (RANGIFERI TARANDUS L)
}

By

Claes Rehbinder and Lars-Eric Edquist

REHBINDER, CLAES and LARS-ERIC EDQVIST: Influence of stress on some blood constituents in reindeer (Rangiferi tarandus $L$ ). Acta vet. scand. 1981, 22, 480-492. - In reindeer, subjected to stress, marked changes were found in some blood constituents when compared with unstressed animals, i.e. the white blood cell composition, cortisol and urea values.

Mental stress, due to handling appears to be of great importance in reindeer.

Elevated urea values in stressed animals may cause a decreased meat quality.

reindeer; st ress; blood.

The management of semidomestic reindeer exposes the animals to a number of stress factors such as physiological strain during herding, capture with lassos, restraint and different kinds of manual handling. Gatherings and handling of reindeer are reported to affect several blood parameters (Väyrynen 1974, Hyvärinen et al. 1976, Nieminen 1980).

The objective of the present study was to comparatively investigate some blood constituents in unstressed and stressed reindeer.

\section{MATERIAL AND METHODS}

Blood samples were obtained from 3 different groups of animals: 


\section{Group I}

During the third week of August 10 animals ( 6 bulls ( $3-5$ years); 2 females ( 2 and 4 years); 2 calves ( 1 female, 1 male)) resting or grazing in the forest were killed by means of a rifleshot in the head. The weather was dry and sunny, the temperature $+10-12^{\circ} \mathrm{C}$.

\section{Group II}

The fourth week of June 5 female reindeer ( $1-4$ years and 1 calf) kept in a corral at the National Veterinary Institute, Stockholm, were used. The animals were enclosed in a connected pen during feeding ( 1 animal refused to enter the pen and was captured with lasso). After initial sampling (Group II a) they were released into the corral and kept moving during a $2 \mathrm{~h}$ period by a person walking or jogging behind them, whereafter they were recaptured with a lasso for final sampling (Group II b). The weather was sunny and humid, the temperature was $+21^{\circ} \mathrm{C}$.

\section{Group III}

In connection with the regular September (20th) bull slaughter in the Mestos forest reindeer herd 10 animals were selected ( 4 bulls ( $2-7$ years); 3 females ( $3-7$ years); 3 calves ( 2 females, 1 male)). The animals had been subjected to 1 day of gathering and herding into a large grazing corral where they rested during the night. The next day they were driven into a small (60 $\mathrm{m}$ in diameter) selection corral, captured with a loop on a pole and put into a small pen from where they were taken out by hand and slaughtered. The work was performed very calmly. The weather was dry and sunny, the temperature was $+4^{\circ} \mathrm{C}$.

Blood samples were taken from the shot animals by a knifecut in the jugular vein into tubes containing heparin or no anticoagulant. Blood samples from the other animals were collected from the jugular vein using $10 \mathrm{ml}$ vacutainer tubes (BectonDickinson) containing heparin or no anticoagulant.

Blood smears were made at the time of collection, allowed to air dry and later stained according to May-Grünewald-Giemsa.

Cortisol concentrations in blood plasma were determined by a competitive protein binding technique utilizing horse plasma 
as described by Lundström et al. (1975). No efforts were undertaken to separate cortisol from other corticosteroids showing cross-reaction in the assay system (e.g. corticosterone $32 \%$; 11-desoxycortisol $20 \%$ ).

Hematocrit (B-EVF) was determined by centrifugation for $3 \mathrm{~min}$ at $12,000 \mathrm{r}$ m in an Adam's Autocrit centrifuge (ClayAdams, Inc., New York).

Hemoglobin $(\mathrm{Hb})$ was determined as cyanmethemoglobin.

Total erythrocyte (RBC) and leucocyte values were determined by counting in a Bürker chamber.

Plasma urea and glucose values were determined by the use of a Glucose/Urea/Creatinine analyser (IL 919; Instrumentation Laboratories) using reagents and procedures recommended by the manufacturer.

Aspartate aminotransferase (ASAT), alanin aminotransferase (ALAT) and alkaline phosphatase (ALP) were determined by kinetic techniques on a LKB Reaction Rate Analyzer according to the recommendations of the Scandinavian Committee on Enzymes (Anon. 1974).

The animals of Groups I and III were necropsied. Material for histological investigation was taken from kidney, liver, heart and also from macroscopically evident lesions elsewhere. The material was fixed in $10 \%$ formal saline. Sections were stained with hematoxylin-eosin, periodic-acid-Schiff and frozen sections with Sudan III.

\section{RESULTS}

The blood picture of the shot unstressed animals (Group I) appeared different when compared with the Groups II and III subjected to different kinds of stress. In the unstressed animals the total white blood count was lower and the number of lymphocytes higher than the number of neutrophils and with comparatively lower numbers of band neutrophils and immature cells (Figs. 1 and 2).

The increase of neutrophils, band neutrophils and unmature cells is striking in the experimental group after stress (II b) but also Group III exhibits a lower number of lymphocytes than neutrophils and, compared to Group I, higher numbers of band neutrophils and immature cells (Figs. 1 and 2). In the experimental animals a decrease in the number of lymphocytes is produced in 4 out of 5 animals and in all animals a decrease in the 


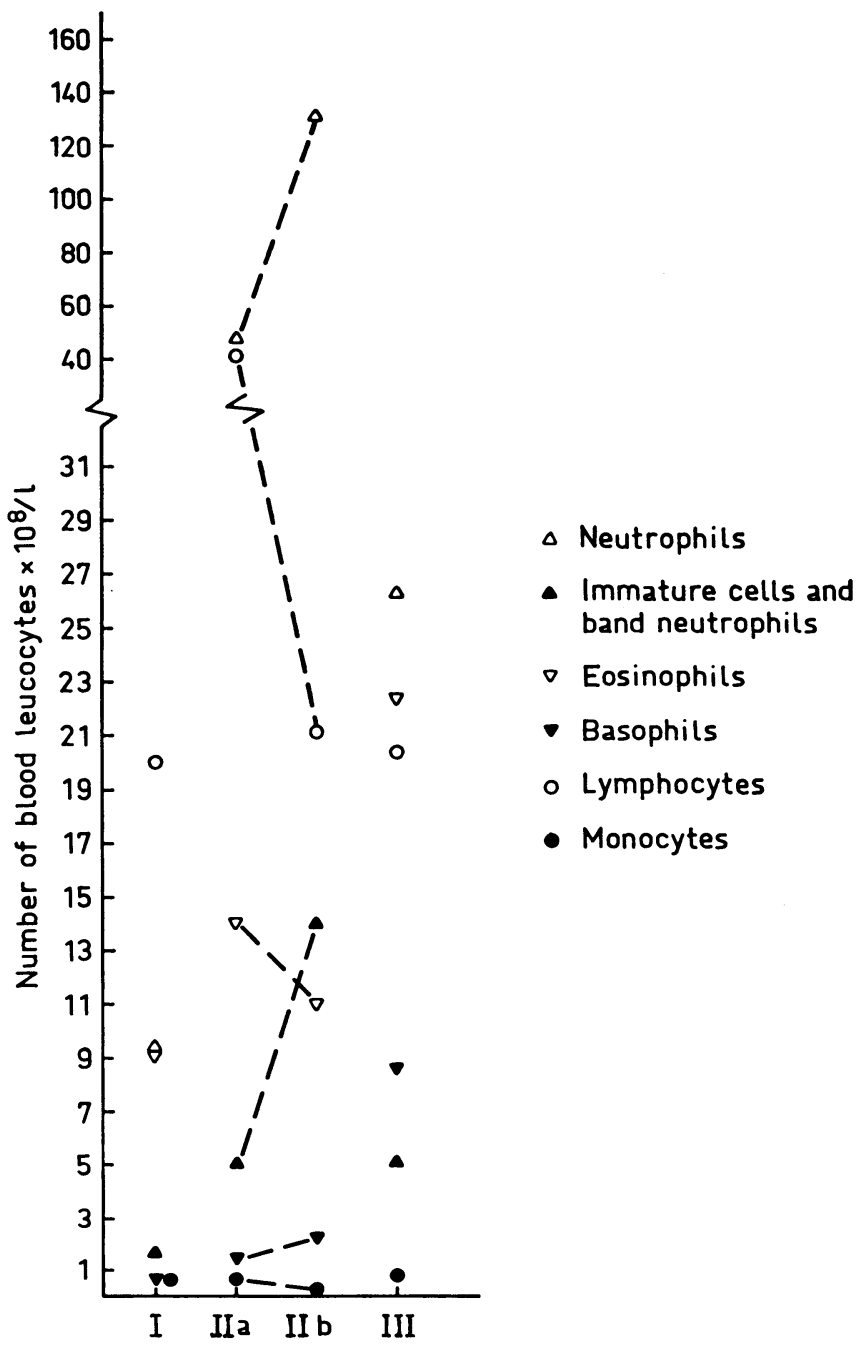

Figure 1. Mean values of number of blood leucocytes in stressed and unstressed reindeer.

I = Unstressed animals; Group I

II a $=$ Experimental nimals; Group II a

II $\mathbf{b}=$ Experimental animals; Group II b

III = Stressed animals, slaughter event; Group III

number of eosinophils occurred (Figs. 1 and 2). The number of eosinophils varies considerably between the groups as does the number of basophils (Figs. 1 and 2). Moderately higher values in packed cell volume, hemoglobin and total erytrocytes were found in the experimental animals after stress (Group II b) and the animals selected for slaughter (Group III; Table 1). 


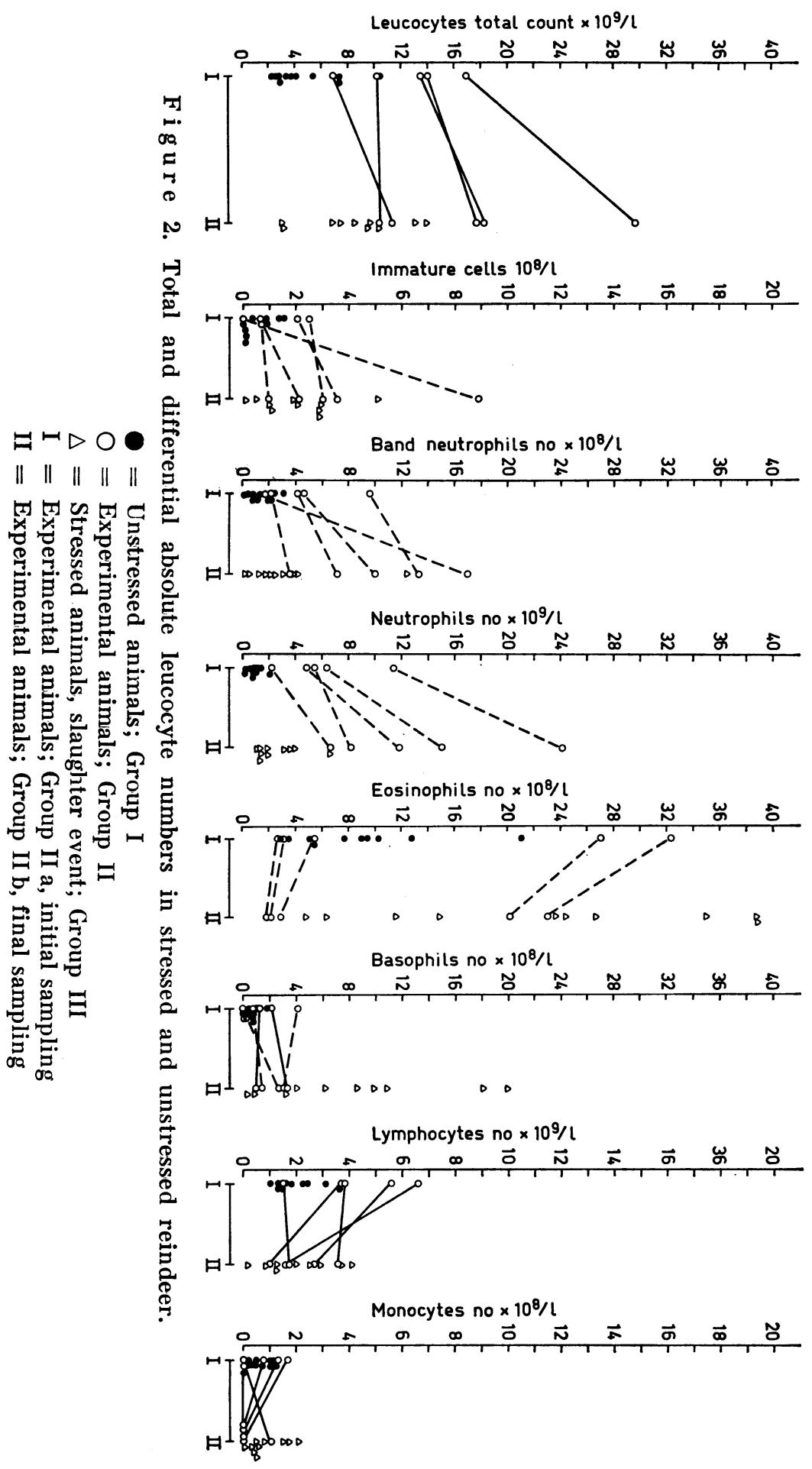


T a b l e 1. Results for some blood constituents in stressed and unstressed reindeer. For details of grouping of animals, see the Material and Method section.

\begin{tabular}{|c|c|c|c|c|c|c|c|c|}
\hline $\begin{array}{l}\text { Groups of } \\
\text { animals }\end{array}$ & & $\begin{array}{l}\mathrm{Hb} \\
\mathrm{g} / \mathbf{1}\end{array}$ & $\begin{array}{l}\text { EVF } \\
\%\end{array}$ & $\begin{array}{l}\mathrm{RBC} \\
\times 10^{12} / 1\end{array}$ & $\begin{array}{l}\text { Blood } \\
\text { glucose } \\
\text { mmol/1 }\end{array}$ & $\begin{array}{l}\text { Plasma } \\
\text { glucose } \\
\text { mmol/1 }\end{array}$ & $\begin{array}{l}\text { ALAT } \\
\mu \text { kat } / 1\end{array}$ & $\begin{array}{l}\text { ALP } \\
\mu \text { kat } / 1\end{array}$ \\
\hline I $(N=10)$ & $\begin{array}{l}\text { Mean } \\
\text { Range }\end{array}$ & $\begin{array}{l}163 \\
144-179\end{array}$ & $\begin{array}{l}47 \\
42-53\end{array}$ & $\begin{array}{l}7.5 \\
6.6-9.4\end{array}$ & $\begin{array}{l}4.5 \\
2.9-6.4\end{array}$ & $\begin{array}{l}5.9 \\
3.8-11.6\end{array}$ & $\begin{array}{l}0.5 \\
0.4-0.6\end{array}$ & $\begin{array}{l}13.1 \\
7.2-25.5\end{array}$ \\
\hline II a $(\mathrm{N}=5)$ & $\begin{array}{l}\text { Mean } \\
\text { Range }\end{array}$ & $\begin{array}{l}153 \\
128-176\end{array}$ & $\begin{array}{l}42 \\
37-50\end{array}$ & $\begin{array}{l}8.9 \\
6.5-12.8\end{array}$ & $\begin{array}{l}3.8 \\
1.8-6.0\end{array}$ & $\begin{array}{l}5.9 \\
4.0-8.5\end{array}$ & $\begin{array}{l}1.0 \\
0.6-1.1\end{array}$ & $\begin{array}{l}7.8 \\
4.3-13.5\end{array}$ \\
\hline II b $(\mathrm{N}=5)$ & $\begin{array}{l}\text { Mean } \\
\text { Range }\end{array}$ & $\begin{array}{l}157 \\
128-178\end{array}$ & $\begin{array}{l}43 \\
35-48\end{array}$ & $\begin{array}{l}9.0 \\
7.4-12.0\end{array}$ & $\begin{array}{ll}4.7 & \\
2.6 & -6.4\end{array}$ & $\begin{array}{l}7.2 \\
4.9-10.5\end{array}$ & $\begin{array}{l}1.2 \\
0.7-1.7\end{array}$ & $\begin{array}{l}8.2 \\
4.1-15.2\end{array}$ \\
\hline III $(N=10)$ & $\begin{array}{l}\text { Mean } \\
\text { Range }\end{array}$ & $\begin{array}{l}190 \\
143-227\end{array}$ & $\begin{array}{l}51 \\
37-60\end{array}$ & $\begin{array}{l}7.9 \\
6.1-8.8\end{array}$ & $\begin{array}{ll}5.4 & \\
4.4 & 6.7\end{array}$ & $\begin{array}{l}6.6 \\
5.7-8.0\end{array}$ & $\begin{array}{l}0.7 \\
0.5-0.8\end{array}$ & $\begin{array}{l}5.8 \\
1.3-12.2\end{array}$ \\
\hline
\end{tabular}

The glucose levels were found to be higher in plasma as compared to blood. The activity of ALAT was somewhat higher in Group II. ALP activities varied considerably within the groups of animals (Table 1).

The cortisol values were low in the animals of Group I. Group II exhibited markedly higher values at the initial sampling and further elevated values at the second sampling. The values for Group III showed a wide range and were in general considerably high (Fig. 3). The urea levels of Groups II and III were higher than those of Group I. In Group II, a notable increase is seen at the second sampling (Fig. 3).

ASAT activities were found to be at the same level in Groups I and III while Group II at the initial sampling had somewhat higher activity and showed a marked increase at the second sampling (Fig. 3).

At necropsy Group I revealed minor parasitic lesions of the liver and kidney and a moderate infestation of Setaria sp. in the abdominal cavity. The differences were small between animals. Mild to moderate infestations of Onchocerca tarsicola along tendons and joint capsules were present in all animals belonging to Group I. Group III revealed numerous severe parasitic lesions of the liver and moderate parasitic lesions of the kidneys similar to those described by Rehbinder et al. (1979). Heavy infestations of Onchocerca tarsicola was seen in all adult animals and mild infestations in calves. 

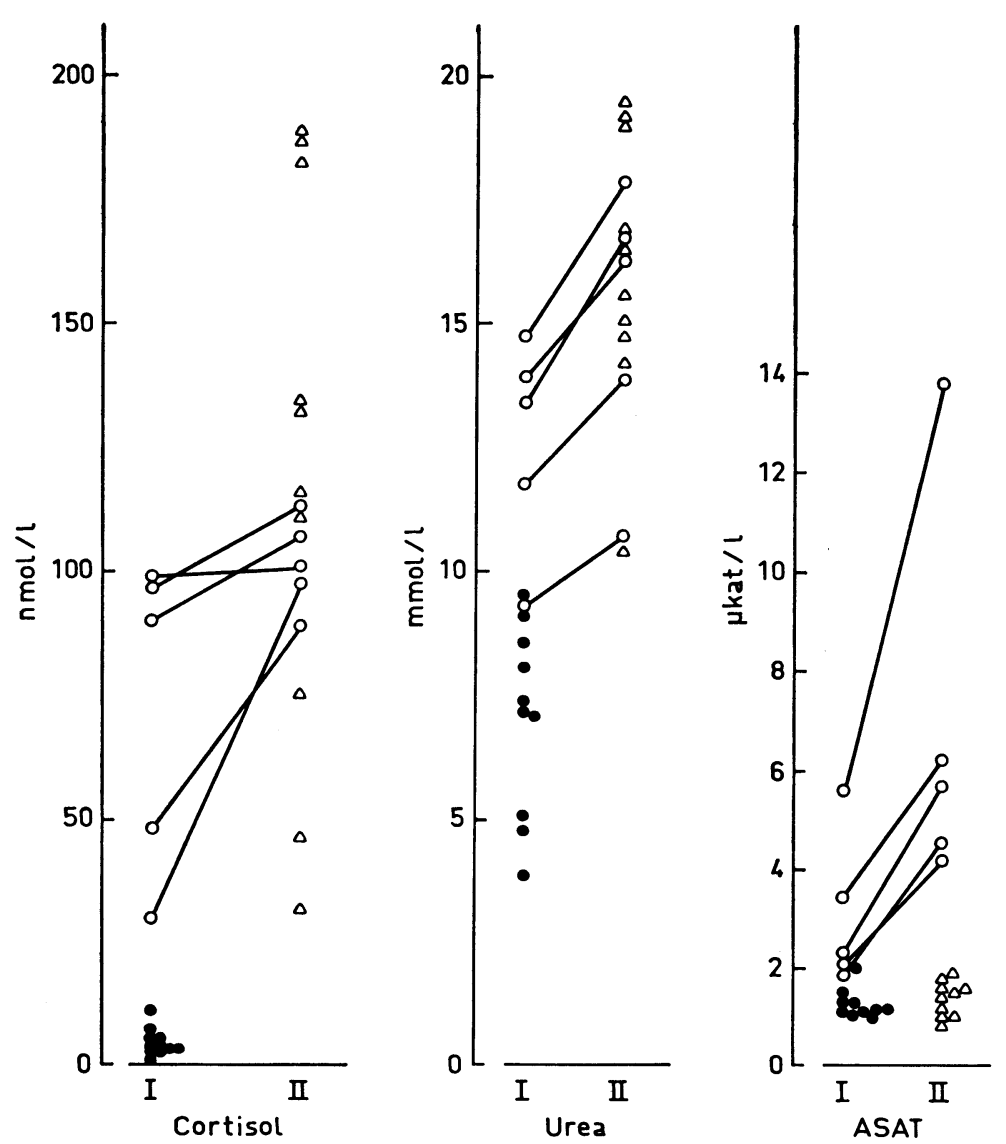

Figure 3. Cortisol, urea and ASAT values in stressed and unstressed reindeer.

- Unstressed animals; Group I

$\mathrm{O}=$ Experimental animals; Group II

$\Delta=$ Stressed animals, slaughter event; Group III

I = Experimental animals; Group II a, initial sampling

II = Experimental animals; Group II b, final sampling

Histological investigations confirmed the parasitological findings but other lesions were not found.

\section{DISCUSSION}

Previously reported values on differential counts of blood leucocytes in reindeer and caribou reveal considerable variations within and between reports (e.g. Yakimoff \& Mitzkewitsch 1931, Gibbs 1960, McEwan 1968, McEwan \& Whitehead 1969, Dieterich 
1970, Drescher-Kaden \& Hoppe 1973, Timisjärvi et al. 1976, Nieminen 1980).

In this investigation there are relatively small variations among the unstressed animals (Group I) yielding a higher number of lymphocytes than neutrophils. In the stressed animals the relation between lymphocytes and neutrophils has changed to a neutrophilia. In the experimental animals (Group II) a decrease in the number of lymphocytes and eosinophils with a contemporaneous increase in neutrophils, bands and immature cells is evident. This interchanged distribution is well known from other animals in connection with different kinds of stress (Winquist 1954, Dvorak 1968, Gartner et al. 1969, Hartman et al. 1973, Jacobsen et al. 1978). The great variation in the distribution of eosinophils and basophils is most likely due to parasitic infections. In the experimental animals an expected decrease is seen after the prolonged stress event. The high number of basophils in animals of Group III may be connected with the presence of numerous dead and alive Setaria sp. in the abdominal cavity. The high number of basophils might be a parallel to the reaction against foreign protein in the guinea pig (Winquist 1960) the dead parasites acting as the source of foreign protein.

Moderate elevations in packed cell volume, hemoglobin and total erythrocyte values were found in the stressed animals (Groups II b and III). The values for these parameters were, however, in all groups within the range of those previously reported by Nieminen (1980).

The higher glucose level in plasma as compared to blood indicates that the red blood cells contain comparatively less glucose. Such a distribution of glucose between plasma and red blood cells have been reported previously for reindeer (Luick et al. 1973). If blood glucose determinations are performed the values ought to be corrected for the erythrocyte dilution. The values recorded here for plasma glucose are similar to those described previously by Luick et al. and Bjarghov et al. (1976).

The activity of ALAT recorded in this study is similar to that reported by Nieminen. Somewhat higher activities were found in the reindeer of Group II. This can probably be attributed to the fact that these animals were less accustomed to physical exercise as compared to the other 2 groups of animals.

From other species it is known that relatively high ALAT activities are present in skeletal muscle cells and it is probable 
that a contribution from this tissue is responsible for the above mentioned difference.

In previous studies determining the activity of ALP in reindeer it has been suggested that high activities measured in calves could reflect a higher degree of bone growth (Bjarghov et al., Nieminen). In the present study the activity of ALP varied markedly within the groups of animals irrespective of age. This is in agreement with previous findings in ruminant species where the wide range of ALP activities in normal cattle and sheep prohibits its use as a diagnostic tool (see Cornelius 1980).

The cortisol levels found in the unstressed animals (Group I) were markedly low compared to the levels found in the experimental animals at initial sampling which reflects a rapid stress response to handling of the latter animals. Previous studies on cortisol levels in reindeer (Yousef et al. 1971, Ringberg LundLarsen et al. 1978) have involved blood sampling after capturing and handling of the animals and the reported concentrations are similar to those found in the animals subjected to handling stress in the present study. It is obvious that physical exercise and additional sampling furthermore increases the cortisol levels reflecting the stress applied on the animals. The experimental animals have to be considered relatively tame as they were in every day contact with people and were also used to sampling but their physical condition compared to the free living animals must be considered poor. Thus the raise of the cortisol values at second sampling may partly be a result of stress in the form of physical exercise. The animals of Group III were semidomesticated and handled carefully. Apparently they were in a generally good physical condition and the physical exercise implied was confined to the moments of fighting when they were roped with a loop. The wide range and generally high cortisol values thus reflects the individual response to herding and handling. Apparently the manual handling of reindeer provokes a rapid stress response as judged from the elevated cortisol levels.

The urea-concentration of the unstressed animals agrees favourably with the levels recorded by Hyvärinen et al. (1975). The elevated urea levels in the stressed animals may have been caused by a reduced urinary excretion and/or an increased urea production. In dehydrated reindeer, plasma and urine urea have been reported to be elevated (Valtonen \& Eriksson 1977). In the present study it was not possible to measure urinary flow or 
urea clearance. As judged from the hemoglobin and hematocrit values some reduction of the plasma volume seems to occur in the stressed animals. There was no indication of pathological processes in the kidney explaining the high urea level in the stressed reindeer. At least some of this elevation may be explained by an increased catabolism of protein from cellular depots, probably muscle tissue. It is known that cortisol exerts such a catabolic effect (see e.g. Wilkinson 1980) and that skeletal muscle in several species such as the rat (Dahlberg et al. 1980) and the pig (Snochowski et al. 1981) contains specific glucocorticoid receptors mediating the hormone action. The findng of elevated cortisol levels in the stressed animals further supports this assumption.

Väyrynen (1974) and Hyvärinen et al. (1976) also found markedly elevated urea values in connection with gatherings. The values were furthermore correlated to the length of the driving distance and time spent in the corral.

The animals of Groups I and III showed the same magnitude of ASAT activity as reported by Bjarghov et al. (1976) and Nieminen (1980). The experimental animals at both sampling occasions showed a higher activity with a pronounced increase between the 2 sampling events.

Elevations of ASAT activities have been reported in connection with muscular disorders and capture myopathies (Cardinet III \& Stephens-Orvis 1980). The higher activity in the experimental animals probably indicates that these animals were physically less adapted to running exercise as they were maintained in a corral and artificially fed, limiting the need for physical movements. The skeletal musculature in these animals is then probably more vulnerable to physical exercise and handling, resulting in leakage of ASAT from muscle cells to the general circulation. Hyvärinen et al. (1976) demonstrated a moderate elevation of ASAT-activity in connection with gatherings and suggested that a considerable, but not severe, stress was imposed on the muscles by the handling procedures.

The established differences, in certain blood parameters between unstressed animals and animals subjected to stress i.e. the change of the white blood cell composition and the elevation of cortisol and urea values in the stressed animals indicate that reindeer are markedly stress susceptible. This is underlined by the marked changes in these values in the experimental animals. 
All animals in the present study were exposed to a low level of physical stress. The major stress event has been mental stress obviously due to the manual handling as such. Consequently mental stress, as reported in pigs (Johansson et al. 1981), appears to be of great importance in the semi-domesticated - half wild reindeer.

Apparently stress has a marked influence on several blood parameters which may explain the differences between different reports. It must be considered almost impossible to obtain normal values in connection with handling and capture of reindeer as many blood constituents will reflect the state of stress in the individual animal.

It is well known among herdsmen that the meat of reindeer which have been herded over long distances and/or have spent a long time in the corral has a urine-like taste. It is obvious from the present investigation that different stress factors may contribute to elevated urea values, which are responsible for the urine-like taste, and thus to a decreased meat quality.

\section{ACKNOWLEDGEMENT}

The skillful technical help by Verena Glatthard is gratefully acknowledged.

\section{REFERENGES}

Anon.: Recommended methods for the determination on four enzymes in blood. Scand. J. clin. Lab. Invest. 1974, 33, 291-306.

Bjarghov, R. S., P. Fjellheim, K. Hove, E. Jacobsen, S. Skjenneberg \& $K$. Try: Nutritional effects on serum enzymes and other blood constituents in reindeer calves (Rangifer tarandus tarandus). Comp. Biochem. Physiol. 1976, 55A, 187-193.

Cardinet III, G. H. \& J. Stephens-Orvis: Skeletal Muscle Function. In: Clinical Biochemistry of Domestic Animals. (Ed. J. J. Kaneko). Academic Press, N.Y. 1980, pp. 545-574.

Cornelius, C. E.: Liver Function. In: Clinical Biochemistry of Domestic Animals (Ed. J. J. Kaneko). Academic Press, New York 1980, pp. 201-250.

Dahlberg, E., M. Snochowski \& J.-Å. Gustafsson: Androgen and glucocorticoid receptors in rat skeletal muscle. Acta chem. scand. 1980, 34, 141-143.

Dieterich, R. A.: Hematological values of some artic mammals. J. Amer. vet. med. Ass. 1970, 157, 604-606.

von Drescher-Kaden, U. \& P. Hoppe: Vergleichende hämatologische Untersuchungen an wildlebenden Wiederkäuern (Rehe, Rotwild, Gemsen, Renntiere). (Different hematological investigations on wild ruminants (roe deer, red deer, chamois, reindeer)). Z. Jagdwiss. 1973, 19, 65--76. 
Dvorak, M.: The effect of traumatic stress on the leucocyte blood picture in the course of the postnatal development of piglets. Acta Univ. Agric. Brno 1968, 37, 537-544.

Gartner, R. J. W., L. L. Callow, C. K. Granzien \& P. M. Pepper: Variations in the concentration of blood constituents in relation to the handling of cattle. Res. Vet. Sci. 1969, 10, 7-12

Gibbs, H. C.: Some haematological values for the barren-ground caribou. Canad. J. comp. Med. 1960, 24, 150-152.

v. Hartman, H., H. Meyer, G. Steinbach \& R. Leirer: Allgemeines Adaptations syndrome beim Jungtier. (General adaptation syndrome in young animals). Mh. Vet.-Med. 1973, 28, 64-70.

Hyvärinen, H., T. Helle, R. Väyrynen \& P. Väyrynen: Seasonal and nutritional effects on serum proteins and urea concentration in reindeer (Rangifer tarandus tarandus L). Brit. J. Nutr. 1975, $33,63-72$.

Hyvärinen, H., T. Helle, M. Nieminen, P. Väyrynen \& R. Väyrynen: Some effects of handling reindeer during gatherings on the composition of their blood. Anim. Prod. 1976, 22, 105-114.

Jacobsen, H. A., R. L. Kirkpatrick, H. E. Burkhart \& J. W. Davis: Hematologic comparisons of shot and live trapped cottontail rabbits. J. Wildlife Dis. 1978, 4, 82-88.

Johansson, G., K. Olsson, J. Häggendal, L. Jönsson \& K. Thorén-Tolling: The effect of stress on myocardial cells and blood levels of catecholamines in normal and amygdalectomized pigs. Canad. J. comp. Med. 1982. In press.

Luick, J. R., S. J. Person, R. D. Cameron \& R. G. White: Seasonal variations in glucose metabolism of reindeer (Rangifer tarandus $\mathrm{L})$ estimated with $\left(\mathrm{U}-{ }^{14} \mathrm{C}\right)$ glucose and $\left(3{ }^{3} \mathrm{H}\right)$ glucose. Brit. J. Nutr. 1973, 29, 245-259.

Lundström, K., W. T. K. Bosu \& B. Gahne: Peripheral plasma levels of corticosteroids in Swedish landrace and Yorkshire boars. Swedish J. agric. Res. 1975, 5, 81-89.

McEwan, E. H.: Hematological studies of barrenground caribou. Canad. J. Zool. 1968, 46, $1031-1036$.

McEwan, E. H. \& P. E. Whitehead: Changes in the blood constituents of reindeer and caribou occurring with age. Canad. J. Zool. 1969, 47, 557-562.

Nieminen, M.: Nutritional and seasonal effects on the haematology and blood chemistry in reindeer (Rangifer tarandus tarandus L). Comp. Biochem. Physiol. 1980, 66A, 399-413.

Rehbinder, C., D. Christensson \& J. Forsell: Investigations on parasitic visceral granulomas in reindeer. Nord. Vet.-Med. 1979, 31, $282-283$.

Ringberg Lund-Larsen, T., J. Kofstand \& A. Aakvaag: Seasonal changes in serum levels of aldosterone, cortisol and inorganic ions in the reindeer (Rangifer tarandus). Comp. Biochem. Physiol. 1978, 60A, 383-386. 
Snochowski, M., K. Lundström, E. Dahlberg, H. Petersson \& L.-E. Edqvist: Androgen and glucocorticoid receptors in porcine skeletal muscle. J. Anim. Sci. 1981, 53, 80-90.

Timisjärvi, J., M. Reinilä \& P. Järvensivu: Haematological values for the Finnish reindeer. Blut 1976, 32, 439-442.

Valtonen, M. \& L. Eriksson: Responses of reindeer to water loding, water restriction and $\mathrm{ADH}$. Acta physiol. scand. 1977, 100, $340-346$.

Väyrynen, P.: The effects of gatherings on blood glucose and lactatic acid concentration. MSc. Thesis. Dep. of Zoology. University of Oulu. 1974, pp. 37.

Wilkinson, J. S.: Pituitary and Adrenal Function. In: Clinical Biochemistry of Domestic Animals (Ed. J. J. Kaneko). Academic Press, New York 1980, pp. 448-484.

Winquist, G.: Morphology of the blood and the hemopoietic organs in cattle under normal and some experimental conditions. Acta anat. 1954, Suppl. $21=1$ Ad. Vol. XXII, pp. 157.

Winquist, G.: Experimental production of basophil granulocytes in the guinea pig. Exp. Cell Res. 1960, 19, 7-12.

Yakimoff, W. L. \& W. J. Mitzkewitsch: Zur haematologie der Renntiere. (On the hematology of the reindeer). Dtsch. tierärztl. Wschr. 1931, 9, 135-136.

Yousef, M. K., R. D. Cameron \& J. R. Luik: Seasonal changes in hydrocortisone secretion rate of reindeer, Rangifer tarandus. Comp. Biochem. Physiol. 1971, 40A, 495-501.

\section{SAMMANFATTNING}

Påverkan av stress pd blodvärden hos ren (Rangiferi tarandus $L$ ).

Hos renar utsatta för stress förelåg markerade förändringar i bl. a. den vita blodbilden, cortisol och ureavärden jämfört med ostressade renar.

Mental stress, förorsakad av den hantering djuren utsättes för synes vara av stor betydelse hos ren.

Förhöjda ureavärden hos stressade renar kan resultera i sänkt köttkvalitet.

(Received August 28, 1981).

Reprints may be requested from: C. Rehbinder, the Department of Pathology, Faculty of Veterinary Medicine, Swedish University of Agricultural Sciences, S-750 07 Uppsala, Sweden. 